\title{
A literature review on Study's methodology of nursing care for Patients with schizophrenia considering their neurocognitive functions
}

\author{
Yusuke Kurebayashi $^{1}$
}

\begin{abstract}
INTRODUCTION; Cognitive dysfunctions of schizophrenia predict daily living problems in patients, and psychiatric nurses should consider neurocognitive abilities of schizophrenic patients. However, development of nursing care considering their neurocognitive function is remains preliminary. To facilitate the development, clarifying the methodology of recent studies is required. AIM; To clarify the methodology of the study of nursing care considering neurocognitive functions of schizophrenic patients and to obtain suggestions for further studies.

METHOD; Electronic databases were searched using key terms.

RESULTS; Nine articles were eligible. Seven articles discussed enhancing neurocognitive functions and only investigated inpatients. The measurement methods used to determine neurocognitive functions varied among the nine articles. Some articles introduced video games or dedicated rooms, while some used structured methods as nursing intervention.

DISCUSSION; Future studies are required to use methods that measure several neurocognitive domains, examine intervention efficacy in outpatients and first-episode patients and develop feasible interventional methods in clinical settings.
\end{abstract}

Keywords: Interventional Study; Literature Review; Neurocognition; Nursing Care; Schizophrenia.

\section{Introduction}

Schizophrenia is a severe mental disorder that typically has an onset during early adolescence and usually has a significant deleterious effect on daily living. This condition is associated with positive symptoms (i.e. hallucinations and delusions) and negative symptoms (i.e. hypobulia and autism). Recently, it was reported that patients with schizophrenia had a decline in their cognitive functioning (Vohringer PA, et al, 2013). Cognitive dysfunction in schizophrenia has been the target for medical interventions (Kroken RA, et al, 2014) because cognitive dysfunctions are separate from other symptoms of schizophrenia (Ventura J. et al, 2010) and can strongly predict outcomes (Oie M, et al, 2011). Moreover, cognitive dysfunction predicts any disabilities of daily living (Lipskaya L, et al, 2011); therefore, psychiatric nursing in schizophrenia should focus on cognitive functioning (Lee H, \& Schepp KG, 2013).

Previous systematic reviews that have examined the efficacy of nursing care in patients with schizophrenia have been published. Stanton \& Happell (2014) reported the results of a systematic

\footnotetext{
${ }^{1}$ Assistant Professor, Faculty of Nursing, Kansai University of Health Sciences, Osaka, Japan, yusukekure@yahoo.co.jp
} 
Kurebayashi, Y. (2016). A literature review on Study's methodology of nursing care for Patients with schizophrenia considering their neurocognitive functions. International Journal of Human Sciences, 13(1), 2019-2031. doi:10.14687/ijhs.v13i1.3734

review that examined the effects of exercise intervention on inpatients with depression, schizophrenia and bipolar disorder. Bradshaw et al (2005), who had examined the effects of healthy living interventions on patients with schizophrenia or schizoaffective disorder, reported that the healthy interventions in their eligible studies had been divided into four types: smoking cessation, weight management, exercise and nutritional education. Hegedus \& Kozel. (2014) reported regarding a systematic review that examined the efficacy of adherence therapy in patients with schizophrenia. Zou et al (2013) conducted a meta-analysis that examined the importance of selfmanagement education intervention in patients with schizophrenia. However, no literature review that examined nursing care that focused on neurocognitive functions of patients with schizophrenia has been conducted, suggesting that there have been few of these types of studies.

To facilitate the development of nursing care that considered neurocognitive functions in patients with schizophrenia, the purpose of this literature review was to assess the trends and methodologies of nursing care research in this area; furthermore, the study aimed to identify valuable suggestions for a further study.

\section{Purpose}

The purpose of this review is to clarify the methodology of the study of nursing care considering neurocognitive functions of schizophrenic patients and to obtain suggestions for further studies.

\section{Method and material 3.1 Date collection}

Electronic databases (Pub Med, CINAHL, Cochrane Library and Japanese Central Review of Medicine) were searched. The search terms used were (schizophrenia) AND (neurocgni* OR cogniti* OR neuropsychology* test) AND (nurs*). The inclusion criteria for this review were articles that investigated or planned to investigate the neurocognitive functions of patients with schizophrenia by using objective tools, and articles that examined or planned to examine nursing care for patients with schizophrenia or articles that were written in Japanese or English. The articles on cognitive behaviour therapy and review articles were excluded. The search period was set until 7 June 2015 in Pub Med, from 1 January 1983 to 7 June 2015 in Japanese Central Review of Medicine and from 1 January 1980 to 11 June 2015 in CINAHL. Moreover, the reference lists of eligible articles were reviewed to identify additional eligible articles. While screening, articles were reviewed and abstraction sheets were introduced to note the specified inclusion criteria for reducing selection bias.

\subsection{Date analysis}

Because this review aimed to assess the trends and methodology of nursing research with respect to nursing care considering patients with schizophrenia, meta-analysis was not introduced in this review. Therefore, eligible articles were examined on the basis of the following four aspects of the study: (1) aim, (2) subjects, (3) tools used for measuring neurocognitive functions and (4) introduction of the interventional nursing care methods.

\section{Results}

The electronic databases identified 411 articles. If the titles or abstracts of those articles indicated that the study was regarding nursing care considering neurocognitive functions for patients with schizophrenia, full-text articles were reviewed. Of 20 articles, 11 were excluded for the following reason: four articles did not measure neurocognitive function, four were not interventional studies, and one did not have a patient with schizophrenia as the subject. After screening these articles, nine were included (Figure 1). While sorting the articles with respect to 
Kurebayashi, Y. (2016). A literature review on Study's methodology of nursing care for Patients with schizophrenia considering their neurocognitive functions. International Journal of Human Sciences, 13(1), 2019-2031. doi:10.14687/ijhs.v13i1.3734

article type, six were interventional studies, two covered the study protocols and one was a case study. The nine articles were examined on the basis of these four aspects.

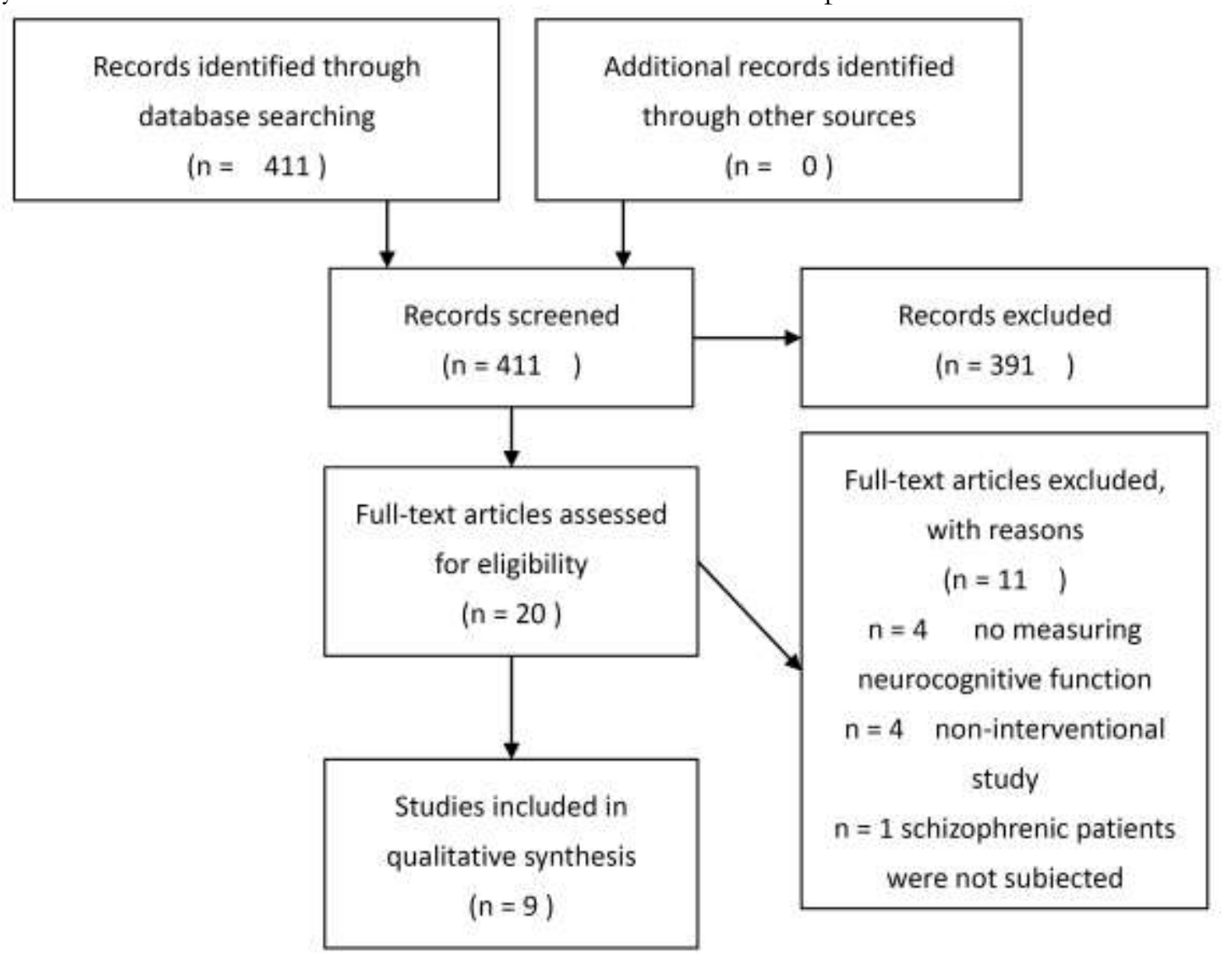

Figure 1. The process of paper selection

\subsection{Aim of eligible articles}

Seven articles were designed to enhance the neurocognitive functions of the patients (Table 1). One article aimed to assist the patient in being compliant with the paint consistently external medications by nursing care considering a patients' level of neurocognitive functions. One article examined the effect of cognitive adaptation training (CAT) on everyday functioning in patients.

\subsection{Subjects of eligible articles}

While sorting articles with respect to stages, eight articles evaluated patients who were in the chronic phase of the disease or who had no acute symptoms (Table 1). One article evaluated patients during their first episode of the disease.

While sorting articles with regard to the site of treatment, seven articles evaluated inpatients and two evaluated outpatients.

\subsection{Tools for measuring neurocognitive functions in eligible articles}

Each eligible article utilized varying tools to measure neurocognitive functions (Table 1). Because cognitive functions could comprise general cognitive function and neurocognitive domains, the tools in eligible articles were divided into two groups. Three articles introduced tools for measuring general cognitive functions (mini-mental state examination or Hasegawa's dementia scale-revision). Six articles introduced the tools for measuring neurocognitive domains (trail making test, continuous performance test or N-back task). Of these six articles, only two articles utilized neurocognitive test batteries (Cogstate schizophrenia battery or CogHealth). 
Kurebayashi, Y. (2016). A literature review on Study's methodology of nursing care for Patients with schizophrenia considering their neurocognitive functions. International Journal of Human Sciences, 13(1), 2019-2031. doi:10.14687/ijhs.v13i1.3734

Table 1 The summary of eligible papers about study design

\begin{tabular}{|c|c|c|c|c|}
\hline $\begin{array}{l}\text { Authors } \\
\text { \&Study design }\end{array}$ & Aim & Subjects & $\begin{array}{l}\text { Tool measuring } \\
\text { Psychometric } \\
\text { symptoms }\end{array}$ & $\begin{array}{l}\text { Tool measuring } \\
\text { neurocognitive } \\
\text { functions }\end{array}$ \\
\hline $\begin{array}{l}\text { Shimozato et } \\
\text { al (2005) }\end{array}$ & $\begin{array}{l}\text { To examine } \\
\text { whether it was } \\
\text { possible to } \\
\text { improve reaction } \\
\text { times in the trail } \\
\text { making test using } \\
\text { computer games. }\end{array}$ & $\begin{array}{l}\text { Right-handed } \\
\text { male inpatients } \\
\text { with chronic } \\
\text { schizophrenia in a } \\
\text { closed ward. }\end{array}$ & $\begin{array}{l}\text { 1. the Brief } \\
\text { Psychiatric } \\
\text { Rating Scale } \\
\text { 2. The Life } \\
\text { Assessment } \\
\text { Scale for the } \\
\text { Mentally III }\end{array}$ & $\begin{array}{l}\text { 1. Trail making } \\
\text { test-part A } \\
\text { 2. Choice reaction } \\
\text { time tasks } \\
\text { 3.Continuous } \\
\text { performance test } \\
\text { (CPT) }\end{array}$ \\
\hline $\begin{array}{l}\text { Dang et al } \\
(2014) \\
\text { Interventional } \\
\text { study }\end{array}$ & $\begin{array}{l}\text { To evaluate the } \\
\text { effects of an iPad- } \\
\text { assisted cognitive } \\
\text { training on } \\
\text { working memory } \\
\text { in a group of male, } \\
\text { first-episode } \\
\text { patients with } \\
\text { schizophrenia. }\end{array}$ & $\begin{array}{l}\text { A total of } 17 \text { male } \\
\text { first-episode } \\
\text { inpatients from } \\
\text { the inpatient unit } \\
\text { at the Shanghai } \\
\text { Mental Health } \\
\text { Center and } \\
\text { Tongde Hospital } \\
\text { of Ahejiang } \\
\text { Province } \\
\text { participated. }\end{array}$ & No measured & $\begin{array}{l}1 . \quad \text { Wechsler } \\
\text { Memory Scale- } \\
\text { Revised } \\
2 . \quad \text { Wechsler } \\
\text { Adult Intelligence } \\
\text { Scale-Revised } \\
\text { (WAIS-R) } \\
\text { 3. N-back } \\
\text { task }\end{array}$ \\
\hline $\begin{array}{l}\text { Kwon et al } \\
(2013) \\
\text { Interventional } \\
\text { study }\end{array}$ & $\begin{array}{l}\text { To examine the } \\
\text { effect of group } \\
\text { music therapy on } \\
\text { brain waves, } \\
\text { behaviour and } \\
\text { cognitive function } \\
\text { among patients } \\
\text { with chronic } \\
\text { schizophrenia. }\end{array}$ & $\begin{array}{l}\text { Participants were } \\
\text { inpatients, } 20 \\
\text { years old or more } \\
\text { and had no acute } \\
\text { psychotic } \\
\text { symptoms. } \\
\text { In the } \\
\text { experimental } \\
\text { group, } \\
\text { participated, } \\
\text { while in the } \\
\text { control group, } 27 \\
\text { participated. }\end{array}$ & $\begin{array}{l}\text { 1. the Nurse's } \\
\text { Obscrvation } \\
\text { Scale for } \\
\text { Inpatients } \\
\text { Evaluation }\end{array}$ & $\begin{array}{l}\text { 1. Mini-mental } \\
\text { state examination } \\
\text { (MMSE) }\end{array}$ \\
\hline
\end{tabular}


Kurebayashi, Y. (2016). A literature review on Study's methodology of nursing care for Patients with schizophrenia considering their neurocognitive functions. International Journal of Human Sciences, 13(1), 2019-2031. doi:10.14687/ijhs.v13i1.3734

Table 1 The summary of eligible papers about study design - Conti

\begin{tabular}{|c|c|c|c|c|}
\hline $\begin{array}{l}\text { Authors } \\
\text { \&Study } \\
\text { design }\end{array}$ & Aim & Subjects & $\begin{array}{c}\text { Tool } \\
\text { measuring } \\
\text { Psychometric } \\
\text { symptoms }\end{array}$ & $\begin{array}{c}\text { Tool measuring } \\
\text { neurocognitive } \\
\text { functions }\end{array}$ \\
\hline $\begin{array}{l}\text { Yong et al } \\
\text { (2011) } \\
\text { Interventio } \\
\text { nal study }\end{array}$ & $\begin{array}{l}\text { To examine the effect } \\
\text { of multisensory } \\
\text { therapy in reducing the } \\
\text { frequency of agitated } \\
\text { behaviours and } \\
\text { improving the } \\
\text { cognition of geriatric } \\
\text { patients with } \\
\text { schizophrenia }\end{array}$ & $\begin{array}{l}\text { Patients who } \\
\text { were } 65 \text { years old } \\
\text { or over, who had } \\
\text { schizophrenia } \\
\text { and who resided } \\
\text { in the long-stay } \\
\text { wards were } \\
\text { included in this } \\
\text { study. Patients } \\
\text { who were in the } \\
\text { acute phase of } \\
\text { their disease were } \\
\text { excluded. }\end{array}$ & $\begin{array}{l}\text { 1. the Cohen- } \\
\text { Mansfield } \\
\text { Agitation } \\
\text { Inventory } \\
\text { 2. The Medal } \\
\text { version of the } \\
\text { Brief } \\
\text { Agitation } \\
\text { Rating Scale }\end{array}$ & 1. MMSE \\
\hline $\begin{array}{l}\text { Takegawa } \\
\text { et al (2014) } \\
\text { Interventio } \\
\text { nal study }\end{array}$ & $\begin{array}{l}\text { To evaluate the effect } \\
\text { of cognitive } \\
\text { rehabilitation }(\mathrm{CR}) \text { on } \\
\text { the cognition of } \\
\text { patients with } \\
\text { schizophrenia. }\end{array}$ & $\begin{array}{l}\text { Participants were } \\
\text { inpatients with } \\
\text { schizophrenia. }\end{array}$ & No measured & $\begin{array}{l}\text { 1. Letter } \\
\text { cancellation } \\
\text { 2. The seven } \\
\text { words memory } \\
\text { task } \\
\text { 3. Trail Making } \\
\text { Test (TMT) }\end{array}$ \\
\hline $\begin{array}{l}\text { Mukai et al } \\
(2009) \\
\text { Interventio } \\
\text { nal study }\end{array}$ & $\begin{array}{l}\text { To examine the effect } \\
\text { of laughter exercise on } \\
\text { cognition and } \\
\text { subjective well-being in } \\
\text { patients with chronic } \\
\text { schizophrenia. }\end{array}$ & $\begin{array}{l}\text { Participants were } \\
\text { inpatients with } \\
\text { chronic } \\
\text { schizophrenia. }\end{array}$ & $\begin{array}{l}1 . \quad \text { The } \\
\text { Subjective } \\
\text { Well-being } \\
\text { Envestory }\end{array}$ & $\begin{array}{l}\text { 1. Hasegawa's } \\
\text { dementia scale- } \\
\text { tevision (HDS-R) }\end{array}$ \\
\hline $\begin{array}{l}\text { Kurebayas } \\
\text { hi et al } \\
\text { (2015) } \\
\text { Case study }\end{array}$ & $\begin{array}{l}\text { To describe the nursing } \\
\text { care that considered } \\
\text { neurocognitive } \\
\text { functions in outpatients } \\
\text { with schizophrenia } \\
\text { facilitate continuously } \\
\text { paint external } \\
\text { medication. }\end{array}$ & $\begin{array}{l}\text { The case was a } \\
60 \text {-year-old } \\
\text { outpatient with } \\
\text { schizophrenia. } \\
\mathrm{He} \text { could not } \\
\text { continuously } \\
\text { paint external } \\
\text { medication. }\end{array}$ & & $\begin{array}{l}\text { 1. } \operatorname{Cog} \text { Health } \\
\text { software battery }\end{array}$ \\
\hline
\end{tabular}


Kurebayashi, Y. (2016). A literature review on Study's methodology of nursing care for Patients with schizophrenia considering their neurocognitive functions. International Journal of Human Sciences, 13(1), 2019-2031. doi:10.14687/ijhs.v13i1.3734

Table 1 The summary of eligible papers about study design - Conti

\begin{tabular}{|c|c|c|c|c|}
\hline $\begin{array}{l}\text { Authors } \\
\text { \&Study } \\
\text { design }\end{array}$ & Aim & Subjects & $\begin{array}{c}\text { Tool measuring } \\
\text { Psychometric } \\
\text { symptoms }\end{array}$ & $\begin{array}{l}\text { Tool measuring } \\
\text { neurocognitive } \\
\text { functions }\end{array}$ \\
\hline $\begin{array}{l}\text { Chan et al } \\
\text { (2014) } \\
\text { Protocol } \\
\text { study }\end{array}$ & $\begin{array}{l}\text { To determine the } \\
\text { effectiveness of a } \\
\text { peer-led self- } \\
\text { management } \\
\text { program for patients } \\
\text { with schizophrenia } \\
\text { in reducing the } \\
\text { severity of psychotic } \\
\text { symptoms, hospital } \\
\text { re-admission and } \\
\text { psychiatric } \\
\text { consultation and in } \\
\text { enhancing } \\
\text { cognition, } \\
\text { empowerment, } \\
\text { functioning levels, } \\
\text { medical adherence, } \\
\text { perceived recovery, } \\
\text { quality of life and } \\
\text { social support. }\end{array}$ & $\begin{array}{l}\text { The participants } \\
\text { will have } \\
\text { schizophrenia and } \\
\text { visit the centres } \\
\text { wherein they are in } \\
\text { a stable condition } \\
\text { without any acute } \\
\text { mental health } \\
\text { crises, who have } \\
\text { not been admitted } \\
\text { to the hospital } \\
\text { because of a } \\
\text { relapse } \\
\text { schizophrenia } \\
\text { symptoms and } \\
\text { who are between } \\
21 \text { and } 65 \text { years } \\
\text { old. }\end{array}$ & $\begin{array}{l}\text { 1. the Positive } \\
\text { and Negative } \\
\text { Syndrome Scale } \\
\text { 2. the Specific } \\
\text { level of } \\
\text { Functioning } \\
\text { Scale } \\
\text { 3. Modified } \\
\text { Empowerment } \\
\text { Scale } \\
\text { 4. the Modified } \\
\text { Recovery } \\
\text { Assessment } \\
\text { Scale-Revised } \\
\text { 5. the Modified } \\
\text { Multidimensional } \\
\text { Scale } \\
\text { Perceived Social } \\
\text { Support } \\
6 . \quad \text { the Drug } \\
\text { Attitude } \\
\text { Inventory } \\
\text { 7. the World } \\
\text { Health } \\
\text { Organization } \\
\text { Quality of Life } \\
\text { Scale-Brief } \\
\text { Version }\end{array}$ & $\begin{array}{l}\text { 1.Cogstate } \\
\text { schizophrenia } \\
\text { battery }\end{array}$ \\
\hline
\end{tabular}


Kurebayashi, Y. (2016). A literature review on Study's methodology of nursing care for Patients with schizophrenia considering their neurocognitive functions. International Journal of Human Sciences, 13(1), 2019-2031. doi:10.14687/ijhs.v13i1.3734

Table 1 The summary of eligible papers about study design - Conti

\begin{tabular}{|c|c|c|c|c|}
\hline $\begin{array}{l}\text { Authors } \\
\text { \&Study } \\
\text { design }\end{array}$ & Aim & Subjects & $\begin{array}{c}\text { Tool measuring } \\
\text { Psychometric symptoms }\end{array}$ & $\begin{array}{l}\text { Tool measuring } \\
\text { neurocognitive } \\
\text { functions }\end{array}$ \\
\hline $\begin{array}{l}\text { Stiekema et } \\
\text { al (2015) } \\
\text { Protocol } \\
\text { study }\end{array}$ & $\begin{array}{l}\text { To evaluate the } \\
\text { effect of } \\
\text { cognitive } \\
\text { adaptation } \\
\text { training (CAT) } \\
\text { as a nursing } \\
\text { intervention in } \\
\text { patients with } \\
\text { severe mental } \\
\text { illnesses who } \\
\text { reside in long- } \\
\text { term clinical } \\
\text { facilities. }\end{array}$ & $\begin{array}{l}\text { A total of } 100 \\
\text { long-term } \\
\text { residential } \\
\text { patients } \\
\text { suffering from } \\
\text { SMI } \\
\text { (including } \\
\text { schizophrenia, } \\
\text { related } \\
\text { psychotic } \\
\text { disorders, } \\
\text { autism, } \\
\text { obsessive- } \\
\text { compulsive } \\
\text { disorder, } \\
\text { personality } \\
\text { disorder, } \\
\text { bipolar } \\
\text { disorder or } \\
\text { major } \\
\text { depression) }\end{array}$ & $\begin{array}{l}\text { 1. the Positive and } \\
\text { Negative Syndrome Scale } \\
\text { 2. the Frontal Systems } \\
\text { Behavior Scale } \\
\text { 3. the Environmental and } \\
\text { Functional Assessment } \\
\text { 4. the Multnomah } \\
\text { Community Ability Scale } \\
\text { 5. the Social and } \\
\text { Occupational } \\
\text { Functioning Scale } \\
\text { 6. the Social Functioning } \\
\text { Scale-other } \\
\text { 7. the Life Skills Profile } \\
\text { 8. the Short Form Health } \\
\text { Survey } \\
\text { 9. } \\
\text { Empowerment the } \\
\text { Questionnaire } \\
\text { 10. the Assessment of } \\
\text { Negative symptoms } \\
\text { 11. the Negative } \\
\text { Symptoms Assessment }\end{array}$ & $\begin{array}{l}\text { 1. The } \\
\text { modified } \\
\text { card sorting } \\
\text { test } \\
\text { 2. WAIS-IV } \\
\text { 3. Word } \\
\text { learning } \\
\text { tasks }\end{array}$ \\
\hline
\end{tabular}

\subsection{Nursing care as an intervention and the effect on neurocognitive functions in eligible articles}

The types of nursing care were different in eligible articles (Table 2). In the protocol study, Chang et al (2014) planned to determine the effect of a peer-led self-management program in patients with schizophrenia. Stiekema et al (2015) planned to evaluate the effect of CAT.

In an interventional study, Dang et al (2014) asked 17 male patients who were experiencing their first episode of schizophrenia to play four video-games using an iPad as the intervention. As a result, only the experimental group improved their accuracy for a two-back task and the response time for a zero-, one- and two-back tasks, while the comparison group did not reveal a change. Furthermore, Shimosato et al (2005), who asked patients playing video-game as interventions, 
Kurebayashi, Y. (2016). A literature review on Study's methodology of nursing care for Patients with schizophrenia considering their neurocognitive functions. International Journal of Human Sciences, 13(1), 2019-2031. doi:10.14687/ijhs.v13i1.3734

reported that the variations of the continuous performance test coefficient of variation in the intervention group were larger than those in the comparison group. Takekava et al (2014) reported that cognitive rehabilitation as performed by trained nurses improved the score for letter cancellation tasks and the trail making test (part B) compared with their scores before intervention. Kwon et al (2013) reported that group music therapy as performed by trained nurses and professionals improved the MMSE score in the experimental group compared with in the comparison group. Mukai \& Nagayoshi (2009) reported that an intervention of laughter exercises

Table 2 The summary of eligible papers about interventions

\begin{tabular}{|c|c|c|c|}
\hline $\begin{array}{c}\text { Authors } \\
\text { \&Study design }\end{array}$ & Intervention & $\begin{array}{l}\text { Duration of } \\
\text { Intervention }\end{array}$ & Main outcome \\
\hline $\begin{array}{l}\text { Shimozato et } \\
\text { al (2005) } \\
\text { Interventional } \\
\text { study }\end{array}$ & $\begin{array}{l}\text { The experimental group } \\
\text { played a computer game as the } \\
\text { intervention. }\end{array}$ & $\begin{array}{l}\text { The } \\
\text { intervention } \\
\text { was conducted } \\
\text { for } 15 \text { min, five } \\
\text { times a week, } \\
\text { for } 3 \text { weeks. }\end{array}$ & $\begin{array}{l}\text { Variations in TMT-A's } \\
\text { coefficient of variation, } \\
\text { and in reaction time of } \\
\text { CP' ' were larger in the } \\
\text { intervention group than in } \\
\text { the comparison group. }\end{array}$ \\
\hline $\begin{array}{l}\text { Dang et al } \\
(2014) \\
\text { Interventional } \\
\text { study }\end{array}$ & $\begin{array}{l}\text { Cognitive training was } \\
\text { performed on iPads that were } \\
\text { provided by the research team. } \\
\text { The research team provided } \\
\text { four user friendly iPad games } \\
\text { for cognitive training in the } \\
\text { experimental group. }\end{array}$ & $\begin{array}{l}\text { Participants } \\
\text { who were } \\
\text { engaged in the } \\
\text { cognitive } \\
\text { training for } 60 \\
\text { min a day, five } \\
\text { days a week, for } \\
4 \text { weeks. }\end{array}$ & $\begin{array}{l}\text { Patients in the } \\
\text { experimental group } \\
\text { significantly improved in } \\
\text { the accuracy rate for two- } \\
\text { back tasks, and in the } \\
\text { reaction time for zero-, } \\
\text { one- and two-back tasks } \\
\text { from baseline to week } 4 \\
\text { compared with those in } \\
\text { the control group. }\end{array}$ \\
\hline $\begin{array}{l}\text { Kwon et al } \\
(2013)\end{array}$ & $\begin{array}{l}\text { The control group received } \\
\text { nursing care, including } \\
\text { psychopharmacology, that had } \\
\text { been routinely provided in } \\
\text { hospitals. The experimental } \\
\text { group participated in the } \\
\text { group music therapy. The } \\
\text { contents of the group music } \\
\text { therapy were integrated using } \\
\text { three music elements of } \\
\text { singing, playing and listening. }\end{array}$ & $\begin{array}{l}\text { The } \\
\text { intervention } \\
\text { was conducted } \\
\text { for twice a week } \\
\text { for } 7 \text { weeks }\end{array}$ & $\begin{array}{l}\text { Alpha waves that were } \\
\text { measured from eight } \\
\text { different sites were } \\
\text { consistently present in the } \\
\text { experimental group and } \\
\text { not in the control group. } \\
\text { The experimental group } \\
\text { also revealed improved } \\
\text { cognitive functions and } \\
\text { positive behaviours while } \\
\text { there were significantly } \\
\text { less negative behaviours } \\
\text { compared with those in } \\
\text { the control group. }\end{array}$ \\
\hline
\end{tabular}


Kurebayashi, Y. (2016). A literature review on Study's methodology of nursing care for Patients with schizophrenia considering their neurocognitive functions. International Journal of Human Sciences, 13(1), 2019-2031. doi:10.14687/ijhs.v13i1.3734

improved the HDS-R score only in the interventional group, whereas there was no change in the comparison group. Yong et al (2011) investigated the effects of multisensory therapy on cognitive functions. Multisensory therapy introduced by trained nurses did not provide changes in the experimental or comparison group.

Table 2 The summary of eligible papers about interventions - Conti

\begin{tabular}{|c|c|c|c|}
\hline $\begin{array}{c}\text { Authors } \\
\& \text { Study design }\end{array}$ & Intervention & $\begin{array}{l}\text { Duration of } \\
\text { Intervention }\end{array}$ & Main outcome \\
\hline $\begin{array}{l}\text { Yong et al } \\
\text { (2011) } \\
\text { Interventional } \\
\text { study }\end{array}$ & $\begin{array}{l}\text { The patients in the } \\
\text { intervention group were } \\
\text { brought into the dedicated } \\
\text { room called 'Snoezenlen } \\
\text { room'. The room was } \\
\text { furnished with items such } \\
\text { as bubble tubes, beanbag } \\
\text { chairs, music and } \\
\text { aromatherapy. } \\
\text { The therapists were } \\
\text { gerontological-trained } \\
\text { nurses. }\end{array}$ & $\begin{array}{l}\text { The } \\
\text { intervention } \\
\text { was } \\
\text { multisensory } \\
\text { therapy } \\
\text { programme of } \\
30 \text { min per } \\
\text { session, two } \\
\text { times per week, } \\
\text { for } 12 \text { weeks. }\end{array}$ & $\begin{array}{l}\text { Participants in the } \\
\text { multisensory therapy group } \\
\text { demonstrated no significant } \\
\text { change in their agitation levels. } \\
\text { No significant change } \\
\text { in cognition was observed. }\end{array}$ \\
\hline $\begin{array}{l}\text { Takegawa et al } \\
\text { (2014) } \\
\text { Interventional } \\
\text { study }\end{array}$ & $\begin{array}{l}\text { The Cognitive } \\
\text { Rehabilitation (CR) was } \\
\text { conducted as intervention } \\
\text { for the participants. }\end{array}$ & $\begin{array}{l}\text { CR was } \\
\text { conducted } 30- \\
60 \text { min per } \\
\text { session, two } \\
\text { times per a } \\
\text { week, for } 3 \\
\text { months. }\end{array}$ & $\begin{array}{l}\text { Significant changes were } \\
\text { observed on letter cancellation } \\
\text { and the seven words memory } \\
\text { task and TMT-B. }\end{array}$ \\
\hline $\begin{array}{l}\text { Mukai \& } \\
\text { Nagayoshi } \\
(2009) \\
\text { Interventional } \\
\text { study }\end{array}$ & $\begin{array}{l}\text { The laughter exercise, } \\
\text { which referred to Jei } \\
\text { Sakakibara's laughing } \\
\text { exercise, was conducted as } \\
\text { the intervention. } \\
\text { Moreover, The } \\
\text { participants watched } \\
\text { comedy videos. }\end{array}$ & $\begin{array}{l}\text { The } \\
\text { intervention } \\
\text { was conducted } \\
15 \text { min a day, } \\
\text { every day, for } 4 \\
\text { weeks. }\end{array}$ & $\begin{array}{l}\text { HDS-R scores at follow-up in } \\
\text { the intervention groups were } \\
\text { significantly improved } \\
\text { compared with the baseline } \\
\text { scores. } \\
\text { The change on SUBI was not } \\
\text { significant in either the } \\
\text { intervention group or the } \\
\text { comparison group. }\end{array}$ \\
\hline
\end{tabular}


Kurebayashi, Y. (2016). A literature review on Study's methodology of nursing care for Patients with schizophrenia considering their neurocognitive functions. International Journal of Human Sciences, 13(1), 2019-2031. doi:10.14687/ijhs.v13i1.3734

Table 2 The summary of eligible papers about interventions - Conti

\begin{tabular}{|c|c|c|c|}
\hline $\begin{array}{l}\text { Authors } \\
\text { \&Study } \\
\text { design }\end{array}$ & Intervention & $\begin{array}{l}\text { Duration of } \\
\text { Intervention }\end{array}$ & Main outcome \\
\hline $\begin{array}{l}\text { Kurebayashi } \\
\text { et al (2015) } \\
\text { Case study }\end{array}$ & $\begin{array}{l}\text { First of all, authors } \\
\text { measured his } \\
\text { neurocognitive functions } \\
\text { using objective tools. } \\
\text { Then, he was provided } \\
\text { with nursing care that } \\
\text { considered his } \\
\text { neurocognitive functional } \\
\text { levels. }\end{array}$ & $\begin{array}{l}\text { The nursing care as } \\
\text { intervention was } \\
\text { conducted for once a } \\
\text { week. }\end{array}$ & $\begin{array}{l}\text { Although he paint } \\
\text { external medication } \\
\text { only } 3 \text { days a week } \\
\text { before the provision of } \\
\text { nursing care, he got } \\
\text { painting external } \\
\text { medication every day } \\
\text { after receiving the } \\
\text { nursing care. }\end{array}$ \\
\hline $\begin{array}{l}\text { Chan et al } \\
(2014) \\
\text { Protocol } \\
\text { study }\end{array}$ & $\begin{array}{l}\text { Standard rehabilitation } \\
\text { program } \\
\text { The control and } \\
\text { experimental groups will } \\
\text { both receive the standard } \\
\text { rehabilitation program } \\
\text { Intervention } \\
\text { The experimental group } \\
\text { will receive PLSMP that } \\
\text { was delivered by peer- } \\
\text { trainers. }\end{array}$ & $\begin{array}{l}\text { PLSMP in the proposed } \\
\text { study will involve six } \\
\text { weekly sessions ( } 2 \mathrm{~h} \\
\text { each). }\end{array}$ & \\
\hline $\begin{array}{l}\text { Stiekema et al } \\
(2015) \\
\text { Protocol } \\
\text { study }\end{array}$ & $\begin{array}{l}\text { All nurses in the } \\
\text { intervention groups have } \\
\text { been trained in CAT by } \\
\text { CAT specialists who were } \\
\text { trained in CAT by Dt. } \\
\text { Velligan. }\end{array}$ & $\begin{array}{l}\text { The study will have a } \\
\text { duration of } 1 \text { year, with } \\
\text { four follow-up } \\
\text { assessments at } 15,18,21 \\
\text { and } 24 \text { months for the } \\
\text { intervention group. } \\
\text { CAT intervention for } \\
\text { the intervention group } \\
\text { will be conducted for } 45 \\
\text { min a week. }\end{array}$ & \\
\hline
\end{tabular}

Of the six interventional studies, five articles revealed the effects on neurocognitive functions. Shimozato et al (2005) reported that the variations in TMT-A's coefficient of variation and reaction time of CPT, which measure attentional function, in the experimental group were larger than those in the comparison group. Dang et al (2014) reported that patients in the experimental group significantly improved with respect to the score of N-back task, which 
Kurebayashi, Y. (2016). A literature review on Study's methodology of nursing care for Patients with schizophrenia considering their neurocognitive functions. International Journal of Human Sciences, 13(1), 2019-2031. doi:10.14687/ijhs.v13i1.3734

measures memory function, from baseline to week 4, compared with those in the control group. Kwon et al (2013) reported that the score of MMSE improved in the experimental group compared with the control group. Takegawa et al (2014) reported that significant changes in TMT-B, which measures memory function, were observed. Mukai \& Nagayosi (2009) reported that HDS-R scores at follow-up in the intervention groups were improved compared with the baseline scores. In contrast, Yong et al (2011) reported that participants in the multisensory therapy group demonstrated no change in MMSE's score.

As for the duration of each intervention session, each intervention was $<60 \mathrm{~min}$ in seven articles, each intervention was $>60 \mathrm{~min}$ in one article and one article did not include the information. With respect to the intervention frequency each week, the sessions occurred $<2$ times per week in six articles, the sessions occurred $>3$ times a week in two articles and one article did not include this information.

\section{Discussion}

The entire body of the study, which had examined the nursing care that considered the neurocognitive functioning ability of patients with schizophrenia, included only nine articles in this review. This suggested that the research has been very limited in this field.

Eight eligible articles reviewed patients who were in the chronic phase of schizophrenia or who did not have acute symptoms. A previous study reported that the neurocognitive functioning of chronic phase patients was worse than that of acute phase patients and that the neurocognitive profiles of patients in the remission phase were different that those of patients in the non-remission phase (Yun DY, et al, 2011). Therefore, the level and profile of neurocognitive functioning depended on the illness stage, and the nursing care for patients with schizophrenia should depend on the stage of illness.

Given that neurocognitive functions in schizophrenia can strongly predict patient outcomes (Oie M. 2011), preventing deterioration of neurocognitive functioning in recent-onset first-episode patients may improve long-term outcomes. This suggested that developing nursing care for firstepisode patients should be focussed on. However, this review found only one study that had evaluated first-episode patients (Dang J. et al), indicating that studies on patients during the first episode have been limited.

All eligible articles in this review included inpatients, except for one article. One previous study revealed that neurocognitive functions in inpatients were different compared with those in outpatients; this suggested that separate investigations of each population (in- and outpatients) should be conducted (Irani F, et al, 2011). The number of outpatients increased with the increasing trend of deinstitutionalization, particularly in Japan. Developing the nursing care for outpatients is required to maintain their neurocognitive function.

The different tools for measuring neurocognitive functions were used in the included articles. Among eligible articles, the number of studies using a test battery was very low (two articles). The trend of using a neurocognitive test battery was also found in clinical trials for the development of medicines to treat neurocognitive dysfunction in schizophrenia. Keefe et al (2013) reviewed the clinical trial study that was completely finished by 2011 and reported that clinical trial studies using a test battery were $14.7 \%$. A recent investigation that measured several neurocognitive domains may also be important. Keefe et al (2013) reported that $79.5 \%$ of clinical trials that were completed in 2011 introduced a test battery. However, there were no gold standards for the test battery, and thus, a gold standard method needs to be developed. In any case, the design of future nursing studies will be required to investigate several neurocognitive domains at once and to identify the effect on the nursing care of neurocognitive domains.

The nursing interventions in each included articles were different. Five articles of six interventional studies reported that nursing care improved cognitive function. However, most interventions in the articles used dedicated devices or rooms and lasted for $60 \mathrm{~min}$ per session twice 
Kurebayashi, Y. (2016). A literature review on Study's methodology of nursing care for Patients with schizophrenia considering their neurocognitive functions. International Journal of Human Sciences, 13(1), 2019-2031. doi:10.14687/ijhs.v13i1.3734

a week. It was very difficult for nursing care to apply this to the general clinical setting. Therefore, feasible methods of nursing care for a clinical setting should be developed.

In contrast, given the self-care theory by Orem, nursing directions not only enhanced the functioning of patients but also compensated for the disability. In other words, arranging the environment for reducing the burden of patient is required. The nursing care strategies, arranging the environment, to reduce neurocognitive dysfunctions in the daily living activities of patients with schizophrenia need to be developed.

This review has a limitation. The number of electronic database, which were searched in this review, were small. Therefore, further reviews are required using more electronic databases.

\section{Conclusion and recommendation}

Nine eligible studies, which had examined the nursing care that considered neurocognitive functions in patients with schizophrenia to assess the trends and methodologies and to obtain suggestion for future study, were examined. The results demonstrated that the trends of these studies were that subjected patients in the chronic phase and outpatients, that few studies used a test battery for measuring neurocognitive functions, and that the interventions in the included studies were complicated. Future studies that consider neurocognitive functions of patients with schizophrenia will be required to examine the effect on first-episode patients or patients in the acute phase and in outpatients; these studies will also investigate the use of a test battery for measuring neurocognitive functions and the development of more convenient interventions in the general clinical setting.

\section{Acknowledgement}

One part of this review was presented in part at the 10th International Nursing Conference, Seoul, Korea on 22-23 October 2015.

The author would like to thank Professor Hitoshi Yoshida in Kansai University of Health Sciences for providing advice on writing the manuscript and Professor Junichi Otaki of Kyorin University, Assistant Professor Midori Takagi, Assistant Professor Satomi Ikeuchi and reader Aiko Hamada of the Kansai University of Health Sciences for offering assistance.

\section{References}

Bradshaw T., Lovell K., Harris N. (2005). Healthy living interventions and schizophrenia: a systematic review. Journal of Advanced Nursing, 49, 634-654.

Chan S. W., Li Z., Klainin-Yobas P., et al. (2014). Effectiveness of a peer-led self-management programme for people with schizophrenia: protocol for a randomized controlled trial. Journal of Advanced Nursing, 70, 1425-1435.

Dang J., Zhang J., Guo Z., et al. (2014). A pilot study of iPad-assisted cognitive training for schizophrenia. Archives of Psychiatric Nursing, 28, 197-199.

Hegedus A. \& Kozel B. (2014) Does adherence therapy improve medication adherence among patients with schizophrenia? A systematic review. International Journal of Mental Health Nursing, 23, 490-497.

Irani F., Kalkstein S., Moberg E. A., et al. (2011). Neuropsychological performance in older patients with schizophrenia: a meta-analysis of cross-sectional and longitudinal studies. Schizophrenia Bulletin, 37, 1318-1326.

Keefe R. S., Buchanan R. W., Marder S. R., et al. (2013). Clinical trials of potential congnitveenhancing drugs in schizophrenia: What have we learned so far? Schizophrenia Bulletin, 39, 417-435.

Kroken R. A., Løberg E. M., Drønen T., et al. (2014). A critical review of pro-cognitive drug targets in psychosis: convergence on myelination and inflammation. Frontiers in Psychiatry, 5, 11. 
Kurebayashi, Y. (2016). A literature review on Study's methodology of nursing care for Patients with schizophrenia considering their neurocognitive functions. International Journal of Human Sciences, 13(1), 2019-2031. doi:10.14687/ijhs.v13i1.3734

Kurebayashi Y., Harada Y., Haga M. (2015). The case report of outpatient with schizophrenia led to continue to paint external medication by nursing care based on assessments of several neurocognitive domains. The Japanese Journal of Rehabilitation Nursing, 4, 47-52. (in Japanese)

Kwon M., Gang M., Oh K. (2013). Effect of the Group Music Therapy on Brain Wave, Behavior, and Cognitive Function among Patients with Chronic Schizophrenia. Asian Nursing Research, 7, 168-174.

Lee H. \& Schepp K. G. (2013). Lessons learned from research with adolescents with schizophrenia and their families. Archives of Psychiatric Nursing, 27, 198-203.

Lipskaya L., Jarus T., Kotler M. (2011). Influence of cognition and symptoms of schizophrenia on IADL performance. Scandinavian Journal of Occupational Therapy, 18, 180-187.

Mukai H., \& Nagayoshi K. (2009). The effects of laughter exercise on cognitive capability in patients with schizophrenia. The Japanese Psychiatric Nursing Society, 52, 348-349. (in Japanese)

Oie M., Sundet K., Ueland T. (2011). Neurocognition and functional outcome in early-onset schizophrenia and attention-deficit/hyperactivity disorder: a 13-year follow-up. Neuropsychology, 25, 25-35.

Shimosato S., Mori C., Itoh K., et al. (2005). Effectiveness of Cognitive Training for Chronic Schizophrenic inpatients in Locked Wards Using Computer Games. The Journal of Nursing Studies, 4. 28-36. (in Japanese)

Stanton R., \& Happell B. (2014). Exercise for mental illness: A systematic review of inpatient studies. International Journal of Mental Health Nursing, 23, 232-242.

Stiekema A. P., Quee P. J., Dethmers M., et al. (2015). Effectiveness and cost-effectiveness of cognitive adaptation training as a nursing intervention in long-term residential patients with severe mental illness: study protocol for a randomized controlled trial. Trials,16, 49.

Takekawa R., Tomita K., Saga N. (2014). The assaults for improvement on neurocognitive functions in patients with schizophrenia. The Japanese Psychiatric Nursing Society, 57, 596-597. (in Japanese)

Vohringer P. A., Barroilhet S. A., Amerio A., et al. (2013). Cognitive impairment in bipolar disorder and schizophrenia: a systematic review. Frontiers in Psychiatry, 4, 87.

Ventura J., Thames A. D., Wood R. C., et al. (2010). Disorganization and reality distortion in schizophrenia: a meta-analysis of the relationship between positive symptoms and neurocognitive deficits. Schizophrenia Research, 121, 1-14.

Yong K. K., Poh C.C., Galistan T.A., et al. (2011). Effects of multisensory therapy on agitated behaviours and cognition of geriatric patients with schizophrenia in a long-term setting- an experimental study. Singapore Nursing Journal, 38, 24-35.

Yun da Y., Hwang S. S., Kim Y., et al. (2011). Impairments in executive functioning in patients with remitted and non-remitted schizophrenia. Progress in Neuro-Psychopharmacology \& Biological Psychiatry, 35, 1148-1154.

Zou H., Li Z., Nolan M. T., et al. (2013). Self-management education interventions for persons with schizophrenia: a meta-analysis. International Journal of Mental Health Nursing, 22, 256-271. 